\title{
Evaluation of health status and meat quality of dumbo catfish Clarias gariepinus maintained using the biofloc system
}

\section{Evaluasi status kesehatan dan kualitas daging ikan lele dumbo Clarias gariepinus yang dipelihara menggunakan sistem bioflok}

\author{
Anang Fajrin ${ }^{1}$, Nurbambang Priyo Utomo ${ }^{1}$, Julie Ekasari $^{*}$, Sri Nuryati ${ }^{1}$ \\ ${ }^{1}$ Department of Aquaculture, Faculty of Fisheries and Marine Science, IPB University, \\ Bogor, West Java, Indonesia \\ *Cooresponding author : j_ekasari@apps.ipb.ac.id
}

(Received November 13, 2017; Accepted June 26, 2020)

\begin{abstract}
This research aimed to evaluate the health status, growth performance, and meat quality of African catfish Clarias gariepinus maintained in biofloc and nonbiofloc systems. This study applied 3 treatments with 4 replications, i.e. K500 (control, a non-biofloc system at a fish stocking density of 500/ $\mathrm{m}^{3}$ ), BF500 (biofloc system at a fish stocking density of $500 / \mathrm{m}^{3}$ ), and BF700 (biofloc system at a fish stocking density of $700 / \mathrm{m}^{3}$ ). The initial body length and bodyweight of the fish used in this experiment were 10-12 $\mathrm{cm}$ and 10-12g, respectively. Feeding was done by using a commercial feed containing $29.76 \%$ protein content. The results showed that fish survival in treatments BF500 and BF700 were significantly different $(\mathrm{P}<0.05)$ from the control. The growth rate of African catfish in the control $(\mathrm{K})$ was the lowest $(3.64 \pm 0.56 \%)$ among the treatments. The results of the organosensory test showed that the application of biofloc systems produced a higher quality of fish meat with a range value of 7-9 compared to that of the control with a range of 6-7. In conclusion, the application of biofloc systems could improve the fish health status, growth performance, and meat quality of African catfish.
\end{abstract}

Keywords: biofloc systems, Clarias gariepinus, density, health status, meat quality

\begin{abstract}
ABSTRAK
Penelitian ini bertujuan mengevaluasi status kesehatan, kinerja pertumbuhan, dan kualitas daging ikan lele Afrika Clarias gariepinus yang dipelihara menggunakan sistem bioflok dan nonbioflok. Penelitian ini menggunakan 3 perlakuan dengan 4 kali ulangan, yang terdiri dari: K500 (kontrol, sistem nonbioflok dengan kepadatan ikan 500 ekor/m³), perlakuan BF500 (sistem bioflok dengan kepadatan ikan 500 ekor/m³), dan perlakuan BF700 (sistem bioflok dengan kepadatan ikan 700 ekor/m³). Ikan yang digunakan berukuran panjang dan bobot awal masingmasing 10-12 cm dan 10-12 g. Pemberian pakan dilakukan dengan menggunakan pakan komersil dengan 29,76\% protein. Hasil penelitian menunjukan tingkat kelangsungan hidup antara perlakuan BF500 dan BF700 berbeda nyata $(\mathrm{P}<0.05)$ dengan perlakuan K500. Laju pertumbuhan ikan lele pada perlakuan K500 lebih rendah dibandingkan perlakuan lain. Hasil pengujian organosensory menunjukkan bahwa ikan yang dipelihara dalam sistem bioflok menghasilkan kualitas daging yang lebih tinggi dengan kisaran nilai 7-9 dibandingkan dengan ikan K500 dengan nilai 6-7. Berdasarkan hasil penelitian ini dapat disimpulkan bahwa aplikasi sistem bioflok dapat meningkatkan status kesehatan, laju pertumbuhan, dan kualitas daging ikan lele Afrika.
\end{abstract}

Kata kunci: bioflok, Clarias gariepinus, kepadatan, kualitas daging, status kesehatan 


\section{INTRODUCTION}

In order to increase production to meet the demand of aquaculture products, culture intensification become a necessity. As a consequence, however, nitrogen waste generated in the system will increase remarkably (Avnimelech, 2007; Dauda et al., 2019). Ammonia is one of the most common inorganic nitrogenous waste in an aquaculture system, which can be critically threatening the welfare of the cultured species. Thereby, ammonia elimination in the culture system is required (Pujiastuti \& Suwartha, 2017). Ammonia reduction in aquaculture system can be conducted by employing heterotrophic bacteria in biofloc systems (BFT). Biofloc system is an alternative method to manage aquaculture waste that was adapted from domestic waste treatment (De Schryver et al., 2008). The main principal of BFT system is ammonia conversion by heterotrophic bacteria into microbial biomass. This microbial biomass could form aggregates that is called biofloc that can be consumed by the cultured organisms (De Schryver et al., 2008).

The biomass formed in biofloc system consist of various microorganism rich in those beneficial components, i.e. enzyme, protein, lipid, carotenoids, an amino sugar, and vitamin (Mabroke et al., 2018). It is potentially used as an additional feed (Husain et al., 2014) and was reported to contribute to the growth performance of the cultured fish. Protein and lipid content in biofloc are considered sufficient to support fish growth, i.e. $24 \%-50 \%$ of protein (Ju et al., 2008; López-Elías et al., 2015) and 0.5\%-3.5\% of lipid (Kuhn et al., 2009; Maicá et al., 2012). Further, Ekasari et al. (2014) and Luo et al. (2014) reported that biofloc contributed to enhance the immunity of Pacific white shrimp and tilapia, respectively. In this regard, this study aimed to evaluate the health status and meat quality of African catfish reared in BFT and non-BFT.

\section{MATERIALS AND METHODS}

\section{Experimental design}

A completely randomized design was applied in this study. There were two biofloc treatments and a control with 4 replications per treatment:

BF500 : stocking density $500 \mathrm{ind} / \mathrm{m}^{3}$ in biofloc system

BF700 : stocking density $700 \mathrm{ind} / \mathrm{m}^{3}$ in biofloc system

K500 : stocking density $500 \mathrm{ind} / \mathrm{m}^{3}$ in nonbiofloc system (control)

\section{Experimental fish rearing}

Seven days before the fish were reared, a commercial probiotic containing Bacillus sp. was inoculated to the rearing media at a dose of $2 \mathrm{~g} / \mathrm{m}^{3}$. The $\mathrm{NH}_{4} \mathrm{Cl}$ was used as the $\mathrm{N}$ source and tapioca as the carbon source, using a $\mathrm{C}: \mathrm{N}$ ratio of 15:1. The daily growth of bacteria was observed until the day before rearing started. The initial body length and bodyweight of the fish used in this experiment were $10-12 \mathrm{~cm}$ and $10-12 \mathrm{~g}$, respectively and it was reared for 45 days. Feeding frequency was twice a day using $5 \%$ of the total biomass (Yusuf et al., 2015). Sampling was done every two weeks and so was the water quality assessment. The observed growth parameters were feed efficiency and daily growth rate. To calculate the later parameters, fish was weighed at the beginning and end of the study, then the average weight was determined.

\section{Challenge test}

A challenge test was conducted at the end of the study using 15 tested catfish for each treatment. Aeromonas hydrophila was incubated at room temperature for $2 \times 24$ hours. A $0.1 \mathrm{~mL}$ of the bacteria were injected in a concentration of $10^{8} \mathrm{CFU} / \mathrm{mL}$. This challenge test was managed for 14 days. Furthermore, mortality, relative percent survival (RPS), and blood profile after the challenge test were observed. Feeding was still done, except on day 7 and day 14. Apart from the other parameters mentioned before, mortality was calculated every day.

\section{Experimental parameters \\ Health status}

The health status of the tested fish was determined through blood profile changes. The blood profile test was conducted on day 0 , day 15 , day 30 , day 45 , and post-challenge test on day 60. The observed parameters were erythrocyte, hemoglobin, hematocrit, and leucocyte differentiation.

\section{Organosensory assessment}

Flesh quality was inspected using the organosensory assessment. The parameters consisted of texture, color, smell, and taste. This assessment was professionally done by panel members and laboratory specialists in a total of 30 people. The panel assessment result was tabulated and followed using quality assessment by comparing the result and the standard requirement in the score sheet (SNI 01-2346-2006). 


\section{Fish nutritional composition}

The fish nutritional composition was assessed by the measurement of proximate composition and glycogen contents. Moisture measurement was done using an oven at a high temperature $\left(110^{\circ} \mathrm{C}\right)$ for 6 hours. Kjeldahl and Folch methods were applied in measuring protein and lipid, respectively. Glycogen analysis was done by diluting the sample using $30 \% \mathrm{KOH}$, saturated $\mathrm{Na}_{2} \mathrm{SO}_{4}$, and $95 \%$ alcohol. The mixture was heated in a water bath $\left(110^{\circ} \mathrm{C}\right)$. After that, it was precipitated. A $0.5 \mathrm{M}$ of $\mathrm{NaOH}$ titration was done, then the mixture was added O-toluidine $+\mathrm{CH}_{3} \mathrm{COOH}$. The last step was done using a spectrophotometer in $635 \mathrm{~nm}$ of wavelength.

\section{Water quality}

The water quality parameters were measured according to the standard procedure by APHA (1998) consisted of temperature, dissolved oxygen (DO), $\mathrm{pH}, \mathrm{TAN}$, nitrite, nitrate, total suspended solids (TSS), floc volume (FV), and culturable bacteria density.

\section{Data analysis}

All data except meat quality by organosensory assessment was tabulated using Ms. Excell 2007 and the statistical analysis was done using SPSS 16 through analysis of variance in $95 \%$ of confidence level. Data homogeneity and normality were analyzed using Levene and Kolmogorov-Smirnov test. The significant results were analyzed using the posthoc Duncan test. Organoleptic assessment was analysed descriptively using scoring method.

\section{RESULTS AND DISCUSSIONS}

\section{Results}

\section{Health status}

On day 30 and 45, there were no significant differences in the blood profile result amongst treatment $(\mathrm{P}>0.05) \quad($ Table 1). However, particularly in day 15 post-challenge test, the leucocyte and haematocrit level was slightly higher in the biofloc treatments compared to that of the control.

\section{Post challenged survival}

After 14 days of challenge test, the fish survival in biofloc treatments were significantly higher compared to the K500 treatment $(\mathrm{P}<0.05)$ (Figure 1).

\section{Meat quality}

The result of the organosensory assessment showed that the average value of the eye, gill,

Table 1. Erythrocyte, leucocyte, hemoglobin ( $\mathrm{Hb})$, and hematocrit (Hc) African catfish flesh reared in a biofloc system and nonbiofloc system with different stock density (before and after challenge test).

\begin{tabular}{|c|c|c|c|c|c|}
\hline Day- & Treatment & $\begin{array}{c}\text { Erythrocyte } \\
\left(\times 10^{6} \text { cell } / \mathrm{mm}^{3}\right) \\
\end{array}$ & $\begin{array}{c}\text { Leucocyte } \\
\left(\times 10^{4} \text { cell } / \mathrm{mm}^{3}\right) \\
\end{array}$ & $\mathrm{Hb}(\mathrm{g} / \mathrm{dL})$ & Hc (\%) \\
\hline \multirow{3}{*}{0} & BF500 & $1.25 \pm 0.08^{\mathrm{a}}$ & $7.73 \pm 0.82^{\mathrm{a}}$ & $5.40 \pm 0.67^{a}$ & $21.20 \pm 3.89^{b}$ \\
\hline & BF700 & $1.43 \pm 0.14^{\mathrm{a}}$ & $8.95 \pm 1.79^{a}$ & $6.10 \pm 0.48^{\mathrm{a}}$ & $26.48 \pm 5.16^{\mathrm{ab}}$ \\
\hline & K500 & $1.37 \pm 0.25^{\mathrm{a}}$ & $6.25 \pm 2.04^{a}$ & $5.30 \pm 1.32^{\mathrm{a}}$ & $17.63 \pm 3.17^{\mathrm{a}}$ \\
\hline \multirow{3}{*}{15} & BF500 & $1.35 \pm 0.19^{\mathrm{a}}$ & $8.09 \pm 1.48^{b}$ & $4.80 \pm 0.99^{a}$ & $26.60 \pm 4.33^{b}$ \\
\hline & BF700 & $1.64 \pm 0.34^{a}$ & $8.63 \pm 0.30^{\mathrm{b}}$ & $5.45 \pm 1.24^{a}$ & $30.28 \pm 4.67^{b}$ \\
\hline & K500 & $1.33 \pm 0.08^{\mathrm{a}}$ & $6.29 \pm 0.83^{\mathrm{a}}$ & $4.60 \pm 0.59^{\mathrm{a}}$ & $16.83 \pm 5.53^{\mathrm{a}}$ \\
\hline \multirow{3}{*}{30} & BF500 & $1.60 \pm 0.44^{a}$ & $8.53 \pm 1.17^{a}$ & $6.90 \pm 0.58^{\mathrm{a}}$ & $25.16 \pm 1.62^{\mathrm{a}}$ \\
\hline & BF700 & $1.56 \pm 0.14^{\mathrm{a}}$ & $8.01 \pm 1.25^{\mathrm{a}}$ & $6.40 \pm 0.16^{\mathrm{a}}$ & $25.68 \pm 4.77^{\mathrm{ab}}$ \\
\hline & K500 & $1.66 \pm 0.26^{\mathrm{a}}$ & $7.81 \pm 0.97^{\mathrm{a}}$ & $8.25 \pm 0.41^{b}$ & $30.68 \pm 2.18^{b}$ \\
\hline \multirow{3}{*}{45} & BF500 & $1.66 \pm 0.31^{\mathrm{a}}$ & $7.31 \pm 0.27^{\mathrm{a}}$ & $6.00 \pm 0.75^{\mathrm{a}}$ & $25.66 \pm 2.94^{a}$ \\
\hline & BF700 & $1.99 \pm 0.14^{\mathrm{a}}$ & $8.22 \pm 1.27^{a}$ & $5.60 \pm 0.16^{\mathrm{a}}$ & $26.30 \pm 4.99^{\mathrm{a}}$ \\
\hline & K500 & $1.78 \pm 0.11^{\mathrm{a}}$ & $6.98 \pm 1.06^{\mathrm{a}}$ & $5.60 \pm 0.63^{\mathrm{a}}$ & $21.46 \pm 4.27^{\mathrm{a}}$ \\
\hline \multirow{3}{*}{$\begin{array}{c}60 \text { (after } \\
\text { challenge } \\
\text { test) }\end{array}$} & BF500 & $1.21 \pm 0.22^{\mathrm{a}}$ & $8.44 \pm 0.63^{a}$ & $5.60 \pm 1.64^{\mathrm{b}}$ & $16.03 \pm 2.81^{\mathrm{a}}$ \\
\hline & BF700 & $1.37 \pm 0.09^{\mathrm{a}}$ & $8.69 \pm 0.61^{\mathrm{a}}$ & $6.95 \pm 0.81^{\mathrm{ab}}$ & $25.77 \pm 3.46^{b}$ \\
\hline & K500 & $1.15 \pm 0.14^{\mathrm{a}}$ & $7.83 \pm 0.44^{\mathrm{a}}$ & $4.95 \pm 0.82^{\mathrm{a}}$ & $17.33 \pm 2.61^{\mathrm{a}}$ \\
\hline
\end{tabular}

Note: *Different superscript in the same column indicates significant difference $(\mathrm{P}<0.05)$. BF500 $=$ stock density $500 \mathrm{ind} / \mathrm{m}^{3}$ in biofloc system; BF700 = stock density $700 \mathrm{ind} / \mathrm{m}^{3}$ in biofloc system; K500 = stock density $500 \mathrm{ind} /$ $\mathrm{m}^{3}$ in non biofloc system (control). 
body mucus, smell, appearance, taste, and texture of the sample was higher in the BF500 and BF700 treatment. The result ranged from 7-9. On the contrary, the K500 treatment showed lower assessment results which ranged from 6-7.

\section{Fish protein}

The protein level retained in the fish in the biofloc treatment was higher and significantly different from $\mathrm{K} 500(\mathrm{P}<0.05)$. On the other hand, the fat level of K500 was higher than those of biofloc treatments. The result of the nitrogen-free extract showed a significant difference $(\mathrm{P}<0.05)$. However, the ash level did not show any significant difference amongst treatments $(\mathrm{P}>0.05)$.

\section{Growth performance}

The African catfish reared in the biofloc system presented a higher result compared to the kontrol (K500) (Figure 2). Unlike the growth result, the feed conversion ratio in the biofloc system was lower (Figure 3).

\section{Water quality}

Water quality during the rearing period were shown below in Table 4 . There were no significant differences amongst treatment. The dominant bacteria density was also identified and counted. Kurthia sp., Enterobacteria sp., and Bacillus sp. were primarily predominantly found in the biofloc treatment. Meanwhile, Kurthia sp., and Bacillus sp. were considered to be minor in the control treatment.

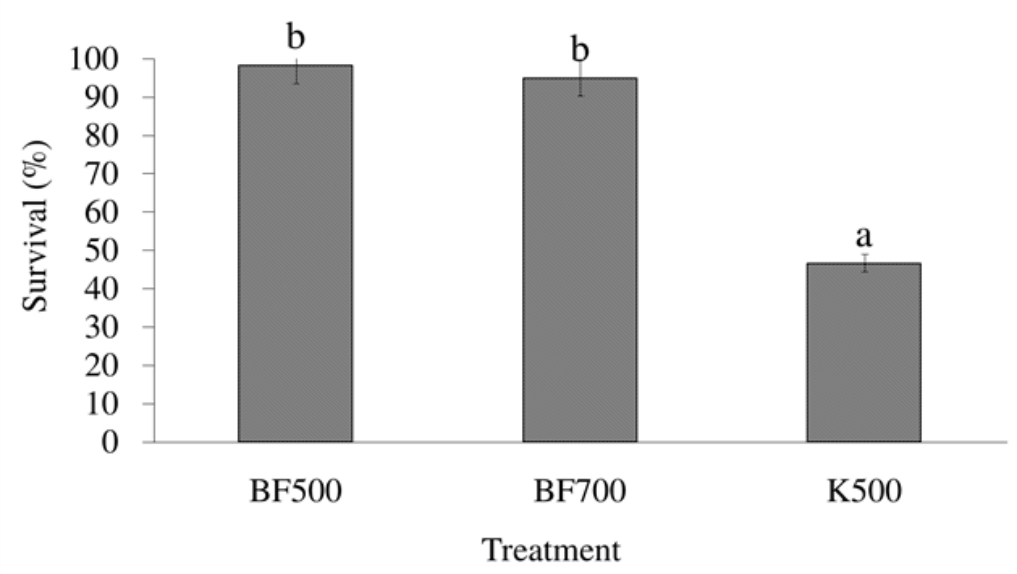

Figure 1. The survival rate of African catfish reared in a biofloc and nonbiofloc system with different stock densities before and after the challenge test towards A. hydrophila. The different superscript indicates a significant difference $(\mathrm{P}<0.05) . \mathrm{BF} 500=$ stock density $500 \mathrm{ind} / \mathrm{m}^{3}$ in biofloc system; BF700 = stock density $700 \mathrm{ind} / \mathrm{m}^{3}$ in biofloc system; $\mathrm{K} 500=$ stock density $500 \mathrm{ind} / \mathrm{m}^{3}$ in non biofloc system (control).

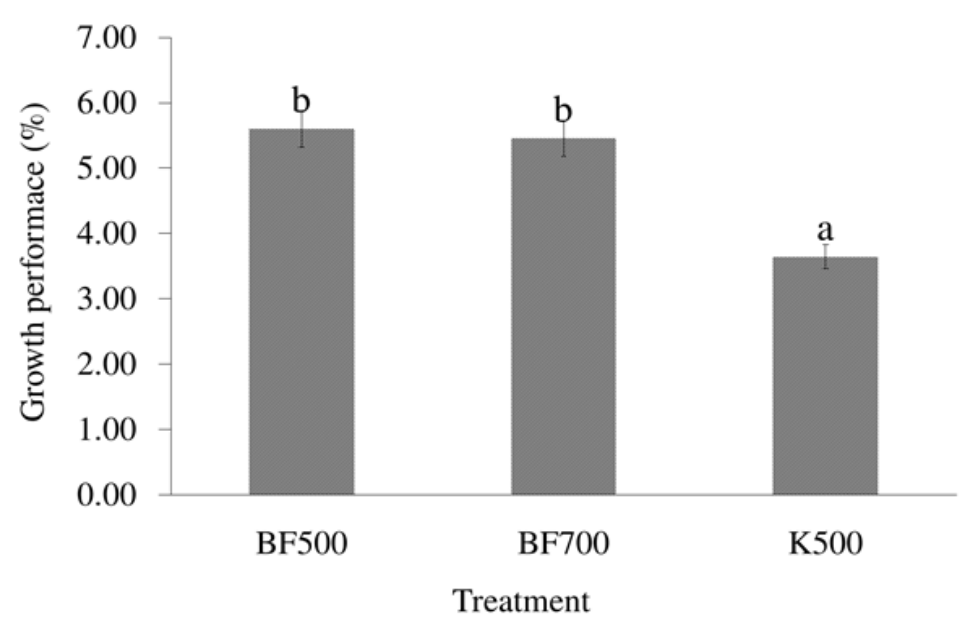

Figure 2. Growth performance of African catfish reared in a biofloc and nonbiofloc with different stock density. The different superscript indicates a significant difference $(\mathrm{P}<0.05)$. BF500 $=$ stock density $500 \mathrm{ind} / \mathrm{m}^{3}$ in biofloc system; BF700 = stock density $700 \mathrm{ind} / \mathrm{m}^{3}$ in biofloc system; $\mathrm{K} 500=$ stock density $500 \mathrm{ind} / \mathrm{m}^{3}$ in non biofloc system (control). 
Table 2. Organosensory analysis of African catfish reared in a biofloc system and nonbiofloc system with different stock density (fresh meat and after being steamed).

\begin{tabular}{cccc}
\hline Parameter & BF500 & BF700 & K500 \\
\hline Fresh & & & 7 \\
Eye & 9 & 9 & 7 \\
Gill & 9 & 9 & 6 \\
Mucus & 9 & 9 & 7 \\
Meat & 8 & 8 & 6 \\
Smell & 8 & 8 & 6 \\
Texture & 8 & 7 & 6 \\
Steamed & & 9 & 7 \\
Appearance & 7 & 8 & 6 \\
Scent & 8 & 8 & 6 \\
Taste & 8 & 8 & 6 \\
Texture & 8 & 8 & s
\end{tabular}

Note: BF500 = stock density $500 \mathrm{ind} / \mathrm{m}^{3}$ in biofloc system; BF700 = stock density $700 \mathrm{ind} / \mathrm{m}^{3}$ in biofloc system; $\mathrm{K} 500=$ stock density $500 \mathrm{ind} / \mathrm{m}^{3}$ in non biofloc system (control). Assessment criteria 1-9.

Table 3. Meat proximate composition of African catfish reared in a biofloc system and nonbiofloc system with different stock density.

\begin{tabular}{cccccc}
\hline \multirow{2}{*}{ Treatment } & \multicolumn{5}{c}{ Proximate composition (\% dry weight) } \\
\cline { 2 - 6 } & Ash & Protein & Lipid & Crude fiber & NFE \\
\hline BF500 & $14.53 \pm 0.78^{\mathrm{a}}$ & $59.13 \pm 0.71^{\mathrm{b}}$ & $19.14 \pm 0.47^{\mathrm{a}}$ & $3.22 \pm 0.53^{\mathrm{a}}$ & $6.44 \pm 0.66^{\mathrm{a}}$ \\
BF700 & $14.26 \pm 0.60^{\mathrm{a}}$ & $58.91 \pm 0.55^{\mathrm{b}}$ & $19.27 \pm 0.65^{\mathrm{a}}$ & $2.83 \pm 0.46^{\mathrm{a}}$ & $4.58 \pm 0.33^{\mathrm{b}}$ \\
K500 & $14.93 \pm 0.55^{\mathrm{a}}$ & $53.94 \pm 0.46^{\mathrm{a}}$ & $21.09 \pm 0.40^{\mathrm{b}}$ & $4.56 \pm 0.13^{\mathrm{b}}$ & $8.78 \pm 0.43^{\mathrm{c}}$ \\
\hline
\end{tabular}

Note: Different superscript indicates significant difference $(\mathrm{P}<0.05)$. BF700 = stock density $700 \mathrm{ind} / \mathrm{m}^{3}$ in biofloc system; K500 = stock density $500 \mathrm{ind} / \mathrm{m}^{3}$ in non biofloc system (control); NFE (Nitrogen-free extract)

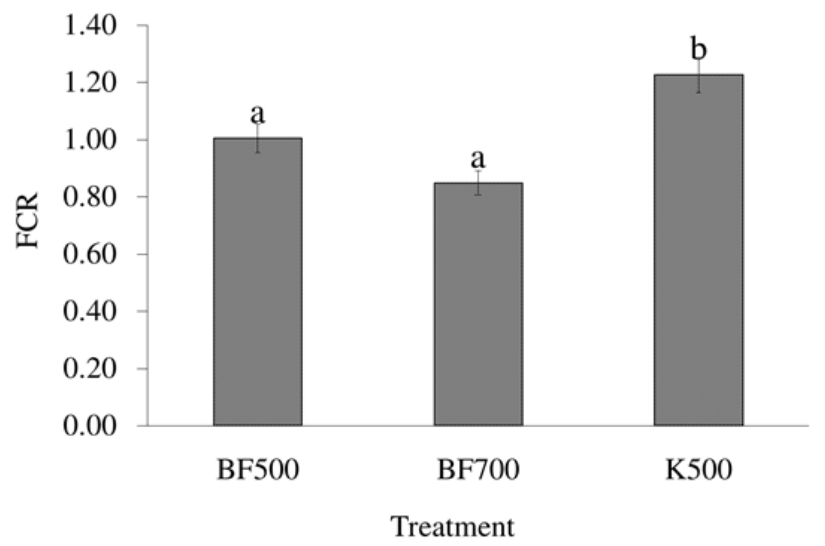

Figure 3. The feed conversion ratio of African catfish reared in a biofloc and nonbiofloc with different stock density. The different superscript indicates a significant difference $(\mathrm{P}<0.05)$. BF500 = stock density 500 ind $/ \mathrm{m}^{3}$ in biofloc system; BF700 = stock density $700 \mathrm{ind} / \mathrm{m}^{3}$ in biofloc system; K500 = stock density $500 \mathrm{ind} / \mathrm{m}^{3}$ in non biofloc system (control). 


\section{Discussion}

The health status of K500 treatment during a 45-day of rearing was considered normal. Bakhshi et al. (2018) stated that the erythrocyte and leucocyte levels of catfish reared in a biofloc system were $0.99-0.1 \times 10^{6} \mathrm{cell} / \mathrm{mm}^{3}$ and $5.9-6.4 \times$ $10^{3} \mathrm{cell} / \mathrm{mm}^{3}$, respectively. The hemoglobin level was at a normal level both in kontrol and biofloc treatment. After the challenge test, the hemoglobin level in the control treatment decreased, while the biolfoc treatment remained normal compared to the previous study by Hastuti and Subandiyono (2018).

In general, the blood profile of the African catfish presented that those which reared in biofloc treatment potentially more resistant to disease. It is confirmed by the challenge test using A. hydrophila. The survival rate after the challenge test was $98.32 \%$ and $95 \%$ for both densities, respectively. Various biofloc studies showed similar results. Aquaculture technology based on biofloc was able to improve immunity in shrimp (Ekasari et al., 2014; Xu \& Pan, 2014). Ekasari et al. (2014) explained that bacteria found in biofloc similarly functioned as probiotics. The poly- $\beta$-hydroxybutyrate content contributed to the fish immunity system hence it promoted greater immunity towards pathogens (Aalimahmoudi \& Azarm, 2017). The availability of protozoa, rotifer, and heterotrophic bacteria also contributed to the high survival rate in the biofloc system since it lowered cannibalism amongst individuals

Table 4. Water quality of African catfish rearing in a biofloc system and nonbiofloc system with different stock density.

\begin{tabular}{cccc}
\hline Parameter & BF500 & BF700 & K500 \\
\hline DO $(\mathrm{mg} / \mathrm{L})$ & $4.95-5.68$ & $5.15-5.85$ & $5.65-6.35$ \\
$\mathrm{pH}$ & $6.55-7.92$ & $6.64-7.83$ & $7.26-7.31$ \\
Temperature $\left({ }^{\circ} \mathrm{C}\right)$ & $28.5-29.0$ & $28.2-28.8$ & $27.8-28.3$ \\
TAN $(\mathrm{mg} / \mathrm{L})$ & $0.15-0.81$ & $0.16-0.82$ & $0.16-0.84$ \\
Nitrite $(\mathrm{mg} / \mathrm{L})$ & $0, .28-0.81$ & $0.26-0.81$ & $0.34-0.88$ \\
Nitrate $(\mathrm{mg} / \mathrm{L})$ & $0.33-0.93$ & $0.31-0.88$ & $0.46-0.93$ \\
TSS $(\mathrm{mg} / \mathrm{L})$ & $367-715$ & $364-733$ & $215-660$ \\
Floc volume $(\mathrm{mL} / \mathrm{L})$ & $70-79$ & $71-80$ & - \\
\hline
\end{tabular}

Note : BF500 = stock density $500 \mathrm{ind} / \mathrm{m}^{3}$ in biofloc system; BF700 = stock density $700 \mathrm{ind} / \mathrm{m}^{3}$ in biofloc system; $\mathrm{K} 500=$ stock density $500 \mathrm{ind} / \mathrm{m}^{3}$ in non biofloc system (control). DO = dissolved oxygen, $\mathrm{TAN}=$ total amonia nitrogen, $\mathrm{TSS}=$ total suspended solids.

Table 5. Bacteria composition in the biofloc and nonbiofloc system.

\begin{tabular}{|c|c|c|}
\hline Treatment & Bacteria genera & Bacteria colony $(\mathrm{CFU} / \mathrm{mL})$ \\
\hline \multirow{3}{*}{ BF500 } & Kurthia sp., Plesiomonas sp. & $3.50 \times 10^{6}$ \\
\hline & Enterobacteria sp. & $1.49 \times 10^{6}$ \\
\hline & Bacillus sp. & $9.52 \times 10^{6}$ \\
\hline \multirow{3}{*}{ BF700 } & Enterobacteria sp. & $4.34 \times 10^{6}$ \\
\hline & Bacillus sp. & $5.54 \times 10^{6}$ \\
\hline & Kurthia sp. & $4.47 \times 10^{6}$ \\
\hline \multirow{3}{*}{ K500 } & Enterobacteria sp. & $1.05 \times 10^{5}$ \\
\hline & Micrococcus sp. & $0.91 \times 10^{5}$ \\
\hline & Campylobacter sp. & $1.18 \times 10^{5}$ \\
\hline
\end{tabular}

Note: BF500 = stock density $500 \mathrm{ind} / \mathrm{m}^{3}$ in biofloc system; BF700 = stock density $700 \mathrm{ind} / \mathrm{m}^{3}$ in biofloc system; $\mathrm{K} 500=$ stock density $500 \mathrm{ind} / \mathrm{m}^{3}$ in non biofloc system (control). 
(Apriyani et al., 2016). Biofloc is also able to boost antioxidant activity because of the carotenoids, vitamin $\mathrm{C}$, and essential fatty acids content (Xu \& Pan, 2012).

The fish proximate composition of the BF500 treatment were $59.13 \%$ of protein, $19.27 \%$ of lipid, $6.44 \%$ of NFE, $14.53 \%$ of ash, and $3.22 \%$ of crude fiber. Those results complied with the past study by Salamah (2014). Yusuf et al. (2015) also stated that the protein and lipid contents were around $59.04 \%$ and $21.98 \%$, respectively. Protein content in the catfish flesh was fairly high. It explained that the biofloc system provided a protein source to support metabolism and health status.

Water quality parameters in the biofloc treatment presented a better result to maintain a decent environment. Nitrite and nitrate were lower compared to K500 treatment. Bacillus sp. in the biofloc treatment diminished excess ammonia to form a protein. Thus it eliminated toxic substances and formed nutrients at once (VanWyk \& Avnimeleh, 2007). Dissolved oxygen in all treatments ranged from 4.95-6.35 and is considered normal. It is supported by Schveitzer et al. (2013) who stated that the DO content in biofloc systems ranged from $4.2-5.9 \mathrm{mg} / \mathrm{L}$. The $\mathrm{pH}$ level varied between 6.55-7.92. According to Ray et al. (2011), pH could vary between 6.3-8.5. Total ammonia nitrogen (TAN) result was $0.15-0.84 \mathrm{mg} / \mathrm{L}$. A decrease in TAN is caused by nitrogen conversion by heterotrophic bacteria (Martinez-Porchasa et al., 2020). Total suspended solids (TSS) ranged from 215-732.5 $\mathrm{mg} / \mathrm{L}$. De Schryver et al. (2008) stated that the recommended range of TSS was $200-1000 \mathrm{mg} / \mathrm{L}$. Sumitro (2017) described that the maximum floc volume in catfish rearing was $80 \mathrm{ml} / \mathrm{L}$. The floc volume in this study which varied between 70-80 $\mathrm{mg} / \mathrm{L}$ was in line with the Sumitro (2017).

Organosensory analysis observed the appearance of eye, gill, body mucus, smell, appearance, taste, and texture. The results showed that the average score of the biofloc treatment varied between 7-9. Meanwhile, the nonbiofloc treatment presented a lower score which ranged from 6-7. Referring to SNI 01-2729.1.2006, the minimal score to fulfill the quality and food safety standard of organoleptic analysis was 7. A lower score will be categorized as unsafe (Nurjanah, 2011). The microbial activity also contributed to the flesh quality changes (Wijayanti \& Lukitasari,
2008). Probiotic in biofloc system was assumed to prevent decomposition process. Thus the appearance of fish reared in the biofloc system was better than the one reared in the nonbiofloc system. Wibowo et al. (2014) stated that texture change was characterized by a dented area around the body surface after being pressed. Meat softening happens because protein decomposition becomes smaller molecules such as polypeptides, amino acids, and ammonia. Biofloc application was assumed to slower protein decomposition so that the quality was well-maintained.

Based on the bacteria abundance analysis, Bacillus sp. dominated the population. As many of $9.52 \times 10^{6} \mathrm{CFU} / \mathrm{mL}$ was counted in the BF500, while $5.54 \times 10^{6} \mathrm{CFU} / \mathrm{mL}$ was detected in the BG700. It was supported by Yusuf et al. (2015) who stated that Bacillus sp. abundance in biofloc system varied between $10^{6}-10^{8} \mathrm{CFU} / \mathrm{mL}$. Bacillus sp. is known for its beneficial activity in the digestive tract. It releases the exogenous enzyme to support expenditure energy (Ogello et al., 2014). The energy gap from the previous mechanism will be utilized to support growth.

Biofloc is abundant in various bioactive molecules, such as carotenoids, chlorophyll, phytosterol, bromophenols, and amino sugar (Ju et al., 2008). Biofloc recycles excess waste to maintain the $\mathrm{C} / \mathrm{N}$ ratio and induces heterotrophic bacteria in converting ammonia into microbe biomass (Ogello et al., 2014). It indicates that biofloc can be one of a nutrition source to support fish growth. Biofloc also enhances feed efficiency by the declining feed conversion ratio. Bacillus sp.. as biofloc former, contributes significant growth in catfish rearing and improve feed efficiency. Therefore, feed utilization could be saved up to 10-20\% (De Schryver et al., 2008).

\section{CONCLUSION}

The application of biofloc system could support the health status and improve meat quality of African catfish.

\section{REFERENCES}

Apriyani I, Setiawati M, Budiardi T, Widanarni. 2016. Pangasianodon hypophthalmus (Sauvage, 1878) juvenile production using biofloc technology with different carbon sources. Jurnal Iktiologi Indonesia 16: 75-90. 
Avnimelech Y. 2007. Feeding with microbial flocs by tilapia in minimal discharge bio-flocs technology ponds. Aquaculture 264: 140-147.

Aalimahmoudi M, Azarm HM. 2017. Biofloc new technology and shrimp disease in superintensive aquaculture. International Journal of Fisheries and Aquatic Research 2: 17-21.

Bakhshi F, Najdegerami EH, Manaffar R, Tokmechi A, Farah KR, Jalali AS. 2018. Growth performance, haematology, antioxidant status, immune response, and histology of common carp Cyprinus carpio L. fed biofloc grown on different carbon sources. Aquaculture Research 49: 393-403.

[BSN] Badan Standardiasi Indonesia 2006. SNI SNI 01-2346-2006: Petunjuk pengujian organoleptik dana tau sensori. Jakarta: Badan Standardisasi Nasional.

[BSN] Badan Standardiasi Indonesia 2006. SNI 01-2729.1-2006: Ikan SegarBagian 1: Spesifikasi. Jakarta: Badan Standardisasi Nasional.

Dauda AB, Ajadi A, Tola-Fabunmi AC, Akinwole AO. 2019. Waste production in aquaculture: sources, components and managements in different culture systems. Aquaculture and Fisheries 4: 81-88.

De Schryver P, Crab R, Defoirdt T, Boon N, Verstraete W. 2008. The basics of bio-flocs technology: The added value for aquaculture. Aquaculture 277: 125-137.

Ekasari J, Hanif Azhar M, Surawidjaja EH, Nuryati S, De Schryver P, Bossier P. 2014. Immune response and disease resistance of shrimp fed biofloc grown on different carbon sources. Fish \& Shellfish Immunology 41: 332-339.

Hastuti S, Subandiyono. 2018. Haematological parameters of the North African catfish Clarias gariepinus farmed using biofloc technology. AACL Bioflux 11: 1415-1424.

Husain, B., Putri dan Supono, 2014. Perbandingan karbon dan nitrogen pada sistem bioflok terhadap pertumbuhan nila merah Oreochromis niloticus. E-Jurnal Rekayasa dan Teknologi Budidaya Perairan 3: 343-350.

$\mathrm{Ju} \mathrm{ZY}$, Forster IP, Conquest L, Dominy W. 2008. Enhanced growth effects on shrimp Litopenaeus vannamei from inclusion of whole shrimp floc or floc fractions to a formulated diet. Aquaculture Nutrition 14: 533-543.

Kuhn DD, Boardman GD, Lawrence AL, Marsh
L, Flick Jr GJ. 2009. Microbial floc meal as a replacement ingredient for fish meal and soybean protein in shrimp feed. Aquaculture 296: 51-57.

López-Elías JA, Moreno-Arias A, MirandaBaeza A, MartínezCórdova LR, Rivas-Vega ME, Márquez-Ríos E. 2015. Proximate composition of bioflocs in culture systems containing hybrid red tilapia fed diets with varying levels of vegetable meal inclusion. North American Journal of Aquaculture 77: 102-109.

Luo G, Wang C, Liu W, Sun D, Li L, Tan H. 2014. Growth, digestive activity, welfare, and partial cost-effectiveness of genetically improved farmed tilapia Oreochromis niloticus cultured in a recirculating aquaculture system and indoor biofloc system. Aquaculture 422-432: $1-7$.

Mabroke RS, el-husseiny OM, zidan AFA, Tahoun A, Suloma A. 2018. Floc meal as potential substitute for soybean meal in tilapia diets under biofloc system conditions. Journal of Oceanology and and Limnology 37: 313320.

Maicá PF, de Borba MR, Wasielesky Jr W. 2012. Effect of low salinity on microbial floc composition and performance of Litopenaeus vannamei (Boone) juveniles reared in a zero water-exchange super-intensive system. Aquaculture Research 3: 361-370.

Martinez-Porchasa M, Ezquerra-Brauerb M, Mendoza-Canoc F, Higuerab JEC, VargasAlboresa F, Martinez-Cordovad LR. 2020. Effect of supplementing heterotrophic and photoautotrophic biofloc, on the production response, physiological condition and postharvest quality of the white leg shrimp, Litopenaeus vannamei. Aquaculture Reports 16: 100257.

Nurjanah, Abdullah, A., Kustiariyah, 2011. Pengetahuan dan Karakteristik: Bahan Baku Hasil Perikanan. Bogor (ID): IPB Press.

Ogello EO, Musa SM, Aura CM, Abwao JO, Munguti JM. 2014. An appraisal of the feasibility of tilapia production in ponds using biofloc technology: a review. International Journal of Aquatic Science 1: 21-39.

Pujiastuti DR, Suwartha N. 2017. Enhancing removal efficiency of ammonia and nitrate in shrimp farm wastewater using biofloc technology and effective microorganism S4 
(EM4). International Journal of Technology 6: 1021-1030.

Ray AJ, Dillon KS, Lotz JM. 2011. Water quality dynamics and shrimp Litopenaeus vannamei production in intensive, mesohaline culture systems with two levels of biofloc management. Aquacultural Engineering 45: 127-136.

Salamah. 2014. Kinerja pertumbuhan ikan lele dumbo Clarias gariepinus yang dikultur pada system bioflok dengan penambahan bakteri heterotrofik. [Tesis]. Bogor: IPB Graduate School.

Schveitzer R, Arantes R, Costódio PFS, do Espírito Santoa CM, Aranaa LV, Seiffert WQ, Andreatta ER. 2013. Effect of different biofloc levels on microbial activity, water quality and performance of Litopenaeus vannamei in a tank system operated with no water exchange. Aquacultural Engineering 56: 59-70.

Sumitro. 2017. Production performance and nitrogen mass balance of intensive catfish Clarias gariepinus culture based on biofloc technology. [Tesis]. Bogor. IPB Graduate School.
VanWyk dan Avnimeleh, 2007. Management of nitrogen cycling and microbial populations in biofloc-based aquaculture system. Word Aquaculture Society 2007. San Antonio Texas.

Wibowo IR, Darmanto YS, Anggo AD. 2014. The effect of killing methods and fish freshness degradation on the quality of fish paste tilapia Oreochromis niloticus. Jurnal Pengolahan dan Bioteknologi Hasil Perikanan 3: 95-103.

Wijayanti NS, Lukitasari L. 2016. Analisis kandungan formalin dan uji organoleptik ikan asin yang beredar di Pasar Besar Madiun. Jurnal Florea 3: 59-64.

Xu WJ, Pan LQ. 2012. Effect of bioflocs on growth performance, digestive enzyme activity and body composition of juvenile Litopenaeus vannamei in zero-water exchange tanks manipulating $\mathrm{C} / \mathrm{N}$ ratio in feed. Aquaculture 356-357: 147-152.

Yusuf MW, Utomo NPB, Yuhana M. Widanarni. 2015. Growth performance of catfish Clarias gariepinus in biofloc-based super intensive culture added with Bacillus sp.. Journal of Fisheries and Aquatic Science 10: 523-532. 